\title{
A perspective on the use of polyphenols nano-formulation as a nutritional strategy to manage the symptoms of the infected patient with COVID-19
}

\author{
Uma perspectiva sobre o uso da nanoformação de polifenóis como estratégia nutricional para \\ controle dos sintomas de paciente infectado com COVID-19
}

Una perspectiva sobre el uso de la nanoformación de polifenoles como estrategia nutricional para el manejo de los síntomas en pacientes infectados por COVID-19

\begin{abstract}
Coronaviruses disease (COVID-19) vaccines have emerged worldwide to control this illness, albeit they cannot guarantee full effectiveness. Polyphenols possess antioxidant, anti-inflammatory, and antiviral properties, all of which may be effective against COVID-19 symptoms. Since polyphenols exhibit low bioavailability, polyphenols nanoformulation (a food technology) have been utilized in COVID-19 patients. Therefore, the purpose of this review is to discuss the current evidence showing the effects of polyphenols nano-formulation in COVID-19 patients. Two previous studies have demonstrated that polyphenols nano-formulation (particularly curcumin) can alleviate clinical manifestation (fever, tachypnea, myalgia, cough) and improve overall recovery since polyphenols can modulate the inflammatory response, oxidative stress, and upregulate certain proteins involved in the renin-angiotensin system, all which play a crucial role on the symptoms caused by COVID-19.
\end{abstract}

Keywords: Nanotechnology; Bioactive ingredients; Functional food; Coronaviruses; Curcumin.

\section{Resumo}

As vacinas contra a doença causada pelo coronavírus (COVID-19) surgiram em todo o mundo para controlar esta doença, embora não possam garantir a eficácia total. Os polifenóis possuem propriedades antioxidantes, antiinflamatórias e antivirais, todas as quais podem ser eficazes contra os sintomas do COVID-19. Uma vez que os polifenóis apresentam baixa biodisponibilidade, a nano-formação de polifenóis (uma tecnologia alimentar) tem sido utilizada em pacientes com COVID-19. Portanto, o objetivo desta revisão é discutir as evidências atuais que mostram os efeitos da nano-formação de polifenóis em pacientes com COVID-19. Dois estudos anteriores demonstraram que a nano-formação de polifenóis (particularmente a curcumina) pode aliviar manifestações clínicas (febre, taquipnéia, mialgia, tosse) e melhorar a recuperação de modo geral, uma vez que os polifenóis podem modular a resposta inflamatória, estresse oxidativo e regular positivamente certas proteínas envolvidas no sistema renina-angiotensina, todos os quais desempenham um papel crucial nos sintomas causados pelo COVID-19.

Palavras-chave: Nanotecnologia; Ingredientes bioativos; Alimento funcional; Coronavírus; Curcumina. 


\begin{abstract}
Resumen
Las vacunas contra la enfermedad por coronavirus (COVID-19) han surgido en todo el mundo para controlar esta enfermedad, aunque no pueden garantizar una eficacia total. Los polifenoles tienen propiedades antioxidantes, antiinflamatorias y antivirales, todas las cuales pueden ser efectivas contra los síntomas del COVID-19. Dado que los polifenoles tienen baja biodisponibilidad, se ha utilizado la nano-formación de polifenoles (una tecnología alimentaria) en pacientes con COVID-19. Por lo tanto, el objetivo de esta revisión es discutir la evidencia actual que muestra los efectos de la nanoformación de polifenoles en pacientes con COVID-19. Dos estudios previos han demostrado que la nano-formación de polifenoles (particularmente curcumina) puede aliviar las manifestaciones clínicas (fiebre, taquipnea, mialgia, tos) y mejorar la recuperación general, ya que los polifenoles pueden modular la respuesta inflamatoria, el estrés oxidativo y regular positivamente ciertas proteínas involucradas en el sistema reninaangiotensina, todos los cuales juegan un papel crucial en los síntomas causados por COVID-19.
\end{abstract}

Palabras clave: Nanotecnología; Ingredientes bioactivos; Comida funcional; Coronavirus; Curcumina.

\title{
1. Introduction
}

The Coronavirus disease (COVID-19), the disease caused by the novel coronavirus, was reported by officials in Wuhan City, China, in December 2019 (Babaei, Nassiri-Asl, Hosseinzadeh, 2020; Zhu et al., 2020). Since the COVID-19 spread rapidly person-to-person, in March 2020, the World Health Organization declared COVID-19 as pandemic (Babaei, Nassiri-Asl, Hosseinzadeh, 2020, 2020; Souza-Volino et al., 2020). Although at least seven different COVID-19 vaccines have emerged in countries, the impact of such vaccines on the pandemic rely on many factors, such as the effectiveness of the vaccines, the period that the vaccines take to be approved, manufactured, and delivered, among others. Furthermore, similar to all other vaccines, the COVID-19 vaccine cannot guarantee full effectiveness.

In this context, it would be essential to establish a coadjutant intervention against COVID-19 to alleviate the symptoms caused by that virus. Polyphenols are food-derived substances (e.g., vegetables, fruit, and cereals) that possess antioxidant, anti-inflammatory, antiviral, and anti-fatigue properties, all of which may effectively mitigate the COVID-19 symptoms (Levy et al. 2020; Oliveira et al., 2021). Previous studies have shown the efficacy of polyphenols against pathogens (e.g., Zika and Dengue virus, influenza virus, and even other virus causing respiratory tract-related infections) (Lin et al., 2015; Levy et al., 2020; Liu et al., 2014), suggesting the polyphenols as a potential nutritional strategy to prevent and/or alleviate symptoms from COVID-19 infection (Babaei, Nassiri-Asl, Hosseinzadeh, 2020, 2020; Soni et al., 2020). Therefore, the purpose of this study is to discuss the current evidence showing the effects of polyphenols nano-formulation on patients diagnosed with COVID-19, exploring the mechanism by which polyphenols can alleviate the COVID-19 symptoms.

\section{Methodology}

This manuscript represents a viewpoint on a specific area of investigation, which includes the effect of polyphenols ingestion on symptoms in patients infected with COVID-19. We have sought in the scientific literature relevant studies to investigate the effect of polyphenols as an antiviral agent that could alleviate symptoms of patients infected with COVID-19. Databases such as SciELO and PubMed were utilized to retrieve scientific articles. Computer search engines utilized the following keywords combined: (“COVID-19" or "coronavirus" or "infections disease" or "SARS-CoV”) AND ("polyphenols" or "antiviral nutrient" or "bioactive compounds" or "curcumin"). Reference list from the retrieved studies was also evaluated as a way to improve the search of the scientific literature. Studies carried out in vitro, animals, and humans were included in this study. Only studies written in the English language were included.

\section{Polyphenols and Their Antiviral Activity}

Polyphenols compounds are present in a variety of terrestrial and marine plants. These molecules are included in diverse chemical substances, which exhibit one or more rings with many hydroxyl groups in their molecular structure (Katz et 
al., 2020). Polyphenols can be classified into phenolic acids, flavonoids, stilbenes, and lignans. Phenolic acids and flavonoids are the most common groups of phenolic compounds in the human diet (Manach et al., 2004). Phenolic acids are found in edible plants, fruits, and cereal grains, such as onion, broccoli, tomato, tea, and red wine, rind of citrus fruit, soybean, green tea, and chocolate (Manach et al., 2004).

Polyphenols are well-known natural substances responsible for playing a critical role in human health, including protection against cardiovascular disease, antioxidant, anti-inflammatory, and antiviral activities, among other biological effects (Oliveira et al., 2021; Chojnacka et al., 2020). Besides these beneficial effects of polyphenols, their antiviral properties have been widely noted in the current literature, as these substances could positively impact COVID-19 (Levy at al., 2020). A large number of studies have demonstrated the efficacy of polyphenols against several pathogens, such as Epstein Barr virus (You et al., 2010; De Leo et al., 2012), enterovirus 71 (Zhang et al., 2015), herpes simplex virus (HSV) (Faith et al., 2006; Annunziata et al., 2018), Zika and Dengue virus (Levy et al., 2020), influenza virus (Lin et al., 2015), and other virus causing respiratory tract-related infections (Zang et al., 2011; Liu et al., 2014).

Current evidence has discussed the possible mechanisms by which polyphenols could attenuate COVID-19 symptoms due to the pleiotropic effect of such substances (Levy et al., 2020; Chojnack et al., 2020). The main mechanism attributable to the polyphenols is their ability to inhibit viral replication by inhibition of immediate-early virus protein expression, inhibition of the nuclear factor $\kappa \mathrm{B}(\mathrm{NF} \kappa \mathrm{B})$ signaling pathway, and activation of the AMP-activated protein kinase/Sirtuin-1 axis in the host cell (Annunziata et al., 2020). For example, Li et al. (2011) investigated the effects of Forsythoside A, a polyphenolic constituent of the fruits of Forsythia suspense, on cell infection by infectious bronchitis virus. It was observed that Forsythoside A decreased viral load and gene expression of contagious bronchitis virus nucleocapsid proteins, suggesting the potential of this bioactive compound as an antiviral agent against infectious bronchitis virus. Moreover, it has also been shown that (-)-catechin gallate and (-)-gallocatechin gallate induces marked anti-SARS-CoV nucleocapsid protein activity (Roh, 2012) (Table 1).

Table 1. Studies carried out in vitro showing the effect of polyphenols against coronavirus

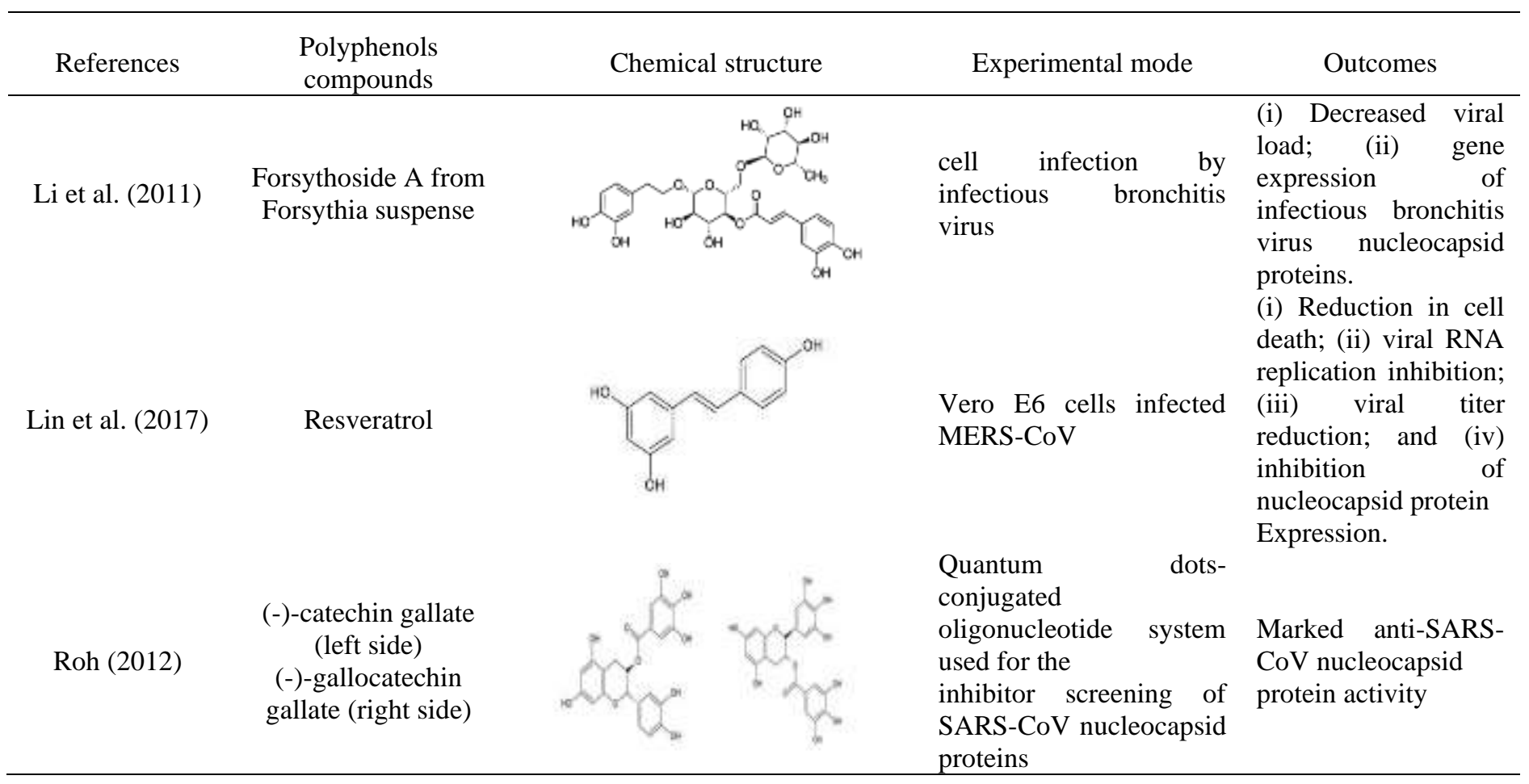




\section{Potential Effect of Polyphenols on Coronavirus}

Although there is a notable amount of specific vaccine that has already been administrated around the world to prevent or control emerging infection of SARS-CoV-2, it is of particular interest to search alternative substances that could attenuate the cellular damage caused by SARS-CoV-2. In this context, using food-derived polyphenols to treat viral infection is promising based on the previous success of treatment with two relevant human coronaviruses, SARS-CoV and the Middle East respiratory syndrome-coronavirus (MERS-CoV) (Annunziata et al., 2020).

A previous study has demonstrated that resveratrol, a polyphenol found in grape and wine, exhibited antiviral activity when assessed on Vero E6 cells infected with MERS-CoV (Lin et al., 2017) (Table 1). It was demonstrated that resveratrol significantly inhibited MERS-CoV infection and prolonged cellular survival after virus infection, decreasing the expression of nucleocapsid protein essential for MERS-CoV replication and down-regulating the apoptosis induced by MERS-CoV in vitro. The authors suggested resveratrol can be a potential antiviral agent against MERS-CoV infection (Lin et al., 2017). It has also been reported that resveratrol can upregulate angiotensin-converting enzyme 2 (ACE2) protein expression, an important component of the renin-angiotensin system (Levy et al., 2020). The ACE2 is a cell surface receptor expressed in various organs, such as the lung, arteries, heart, kidney, and intestine (Hamming et al., 2004).

The ACE2 of the target cell provides anchorage for the spike protein of SARS-CoV-2, which initiates SARS-CoV-2 cellular entry (Shang et al., 2020). Thus, endocytosis of ACE2 occurs during SARS-coronavirus (also for SARS-CoV-2), leading reduction in cell surface levels of ACE2. A result of this fact is the accumulation of angiotensin II since it is a substrate for ACE2. High levels of angiotensin II have been widely associated with acute lung injury in COVID-19, as well as other symptoms, such as inflammation, endothelial damage, hypertension, etc. (Pang et al., 2015). Previous evidence reinforce the association between ACE2 and lung injury, as it has shown that the upregulation of ACE2 expression protected mice from severe acute lung injury (Pang et al., 2015). Therefore, the renin-angiotensin system (with angiotensin II and ACE2 included) has a crucial role in COVID-19.

Curcumin, a polyphenol found in turmeric, can also modulate the level of ACE2 (Soni et al., 2020). Of note, improvement in curcumin-induced expression of ACE2 reflects in the inactivation of angiotensin II, which consequently prevents the elevated angiotensin II level-triggered cellular signaling. A high level of angiotensin II induces an inflammatory response and overproduction of reactive oxygen species (oxidative stress), culminating in pathological consequences. For example, elevated levels of angiotensin II stimulates its receptor, angiotensin II receptor type 1 (AT1 receptor). When high levels of angiotensin II stimulate the AT1 receptor, it induces an inflammatory response, vasoconstriction (which can be associated with hypertension), alters redox balance, leading to acute respiratory distress syndrome. Curcumin, otherwise, can downregulate the expression of the AT1 receptor on several types of cells, reducing the abnormal consequences, such as inflammation and oxidative stress (Soni et al., 2020) (Figure 1). 
Figure 1. Endocytosis of ACE2 occurs during SARS-CoV-2, leading reduction in cell surface levels of ACE2. A result of this fact is the accumulation of angiotensin II since it is a substrate for ACE2. Angiotensin II, in turn, can also stimulate its receptor, angiotensin II receptor type 1 (AT1 receptor), which induces an inflammatory response, vasoconstriction, $\mathrm{NFKB}$ activation, and oxidative stress. Curcumin-mediated inhibition of ACE can reduce the synthesis of angiotensin II. Consequently, the reduced levels of angiotensin II may be accelerated by curcumin-driven enhanced expression of ACE2. Curcumin can prevent the detrimental effects of angiotensin II through the downregulation angiotensin AT1 receptor. Inhibiting angiotensin II-stimulated angiotensin AT1 receptor signaling in COVID-19 by curcumin will hamper the activation of NFkB, reducing exacerbated inflammation response, vasoconstriction, oxidative stress, etc.

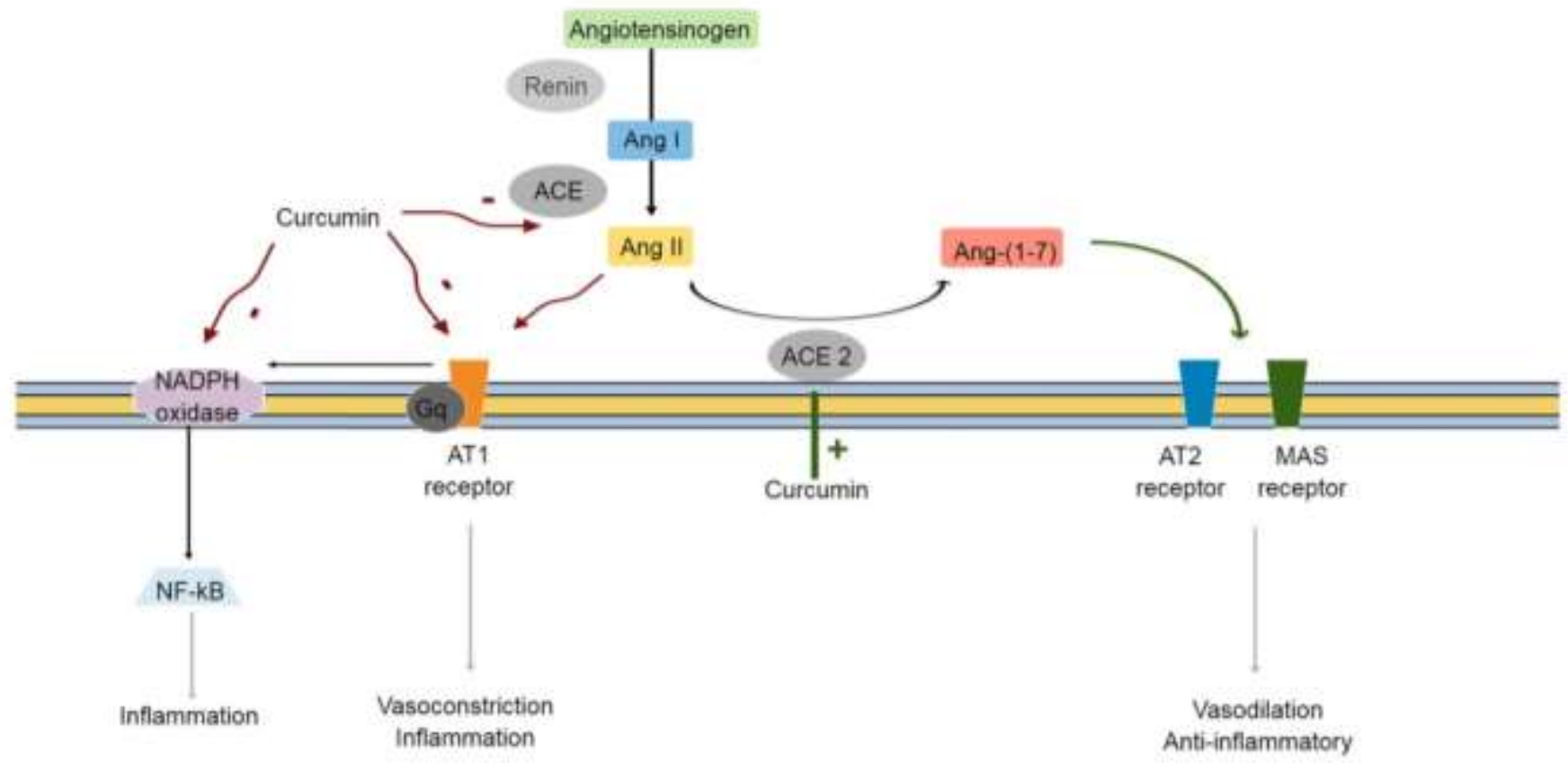

Source: Authors.

The abnormal inflammatory response is a prominent characteristic of COVID-19, as "cytokines storm" is often utilized to refer to the exaggerated pro-inflammatory response associated with the COVID-19 (Hamming et al., 2004). A high level of cytokines may indicate a poor prognosis in COVID-19, and this fact is suspected to be associated with the deaths (Hamming et al., 2004). COVID-19 selectively can induce macrophages to produce pro-inflammatory cytokines, such as

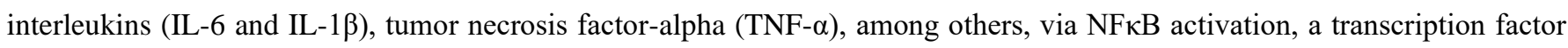
that resides in the cell's cytoplasm (Oliveira et al., 2021). Previous studies have reported that polyphenols can reduce IL-6, IL$1 \beta$, and TNF- $\alpha$ via inhibition of NFKB activation (Oliveira et al., 2021) (Figure 1). Thus, polyphenols might exert a beneficial effect on COVID-19 by modulating inflammatory pathways. However, it is essential to note that most studies reporting the possible impact of polyphenols on a specific pathway involved with COVID-19 have been carried out in vitro and, thus, the benefits of polyphenols intake in COVID-19 patient is still speculative.

\section{Effect of Polyphenols Nano-Formulation on Covid-19 Patients}

To date, only two studies have investigated the effect of polyphenols nano-formulations on COVID-19 patients (Saber et al., 2021; Valizadeh et al., 2020). In an open-label nonrandomized clinical trial, Saber-Moghaddam et al. (2021) sought to evaluate the efficacy of nano-curcumin oral formulation in hospitalized patients with mild-moderate COVID-19. Forty-one 
patients diagnosis with COVID-19 were allocated to nano-curcumin (Sinacurcumin soft gel, contains $40 \mathrm{mg}$ curcuminoids as nanomicelles, two capsules twice a day) or control group for two weeks. A significant faster recovery of COVID-19 symptoms, including fever and chills, tachypnea, myalgia, and cough, was observed in patients treated with nano-curcumin. Furthermore, oxygen saturation was significantly higher in the treatment group after 2, 4, 7, and 14 days of follow-up and lymphocyte count after 7 and 14 days. The author concluded that oral curcumin nano-formulation could significantly improve recovery time in hospitalized COVID-19 patients.

Valizadeh et al. (2020) aimed to evaluate the effects of nano-curcumin on the modulation of inflammatory cytokines in COVID-19 patients. Forty patients were divided into two groups, 20 patients receiving nano-curcumin (Sinacurcumin soft gel, $40 \mathrm{mg}$ curcuminoids as nanomicelles, four capsules daily) and 20 patients receiving placebo, for two weeks. After treatment with nano-curcumin, a significant decrease in IL-6 and IL-1 $\beta$ expression and secretion in serum and supernatant was found. The authors suggested that nano-curcumin may cause an improvement in clinical manifestation and overall recovery since nano-curcumin can modulate the increased rate of inflammatory cytokines (IL-1 $\beta$ and IL-6) mRNA expression and cytokine secretion) in COVID-19 patients.

To date, curcumin is the main polyphenol that has been evaluated on COVID-19 patients. Likely, the pleiotropic effect of curcumin (i.e., anti-inflammatory, upregulation of ACE2, etc.) in several pathways involving the undesired impact of COVID-19 can be the most likely reason for the usage of curcumin in patients diagnosed with COVID-19 (Babaei, Nassiri-Asl, Hosseinzadeh, 2020, 2020; Soni et al., 2020). Moreover, it is noteworthy that the studies investigating the effect of curcumin on COVID-19 have utilized nanomicelles (nanotechnology). Polyphenols nano-formulation has emerged as a food technology that improves the polyphenols bioavailability since these bioactive active molecules are substantially lost during their passage through the gastrointestinal tract, reducing the effectiveness of polyphenols (Oliveira et al., 2021). Curcumin nano-formulation seems to be clinically relevant in COVID-19 patients (and even in other clinical populations), as a previous study has demonstrated that ingestion of curcumin nanoparticles (Theracurmin ${ }^{\circledR}$ ) compared to curcumin powder enhanced the curcumin bioavailability (Sasaki et al., 2011). This fact suggests that curcumin nano-formulation could be an interesting strategy to apply in the clinical fields, considering the pleiotropic effect of polyphenols. Moreover, it is also important to note that curcumin supplementation is both safe and well tolerated, as a previous study showed that supplementation of $5 \mathrm{~g}$ of curcumin in older individuals induces no adverse effect (Barber-chamoux et al., 2018). It has been reported that doseescalating studies have indicated the safety of curcumin at doses $0-3 \mathrm{mg} / \mathrm{kg}$ and up to $12 \mathrm{~g} /$ day over three months (Gupta, Patchva, Aggarwal, 2012).

\section{Conclusion}

The present review suggests that polyphenols nano-formulation, particularly curcumin, could be adequate to manage the symptoms of the infected patient with COVID-19. The findings of the present study should be interpreted with caution since more clinical trials are needed to understand better the consistency and the mechanisms underlying the effects of polyphenols nano-formulation in COVID-19 patients. It is noteworthy that only two studies related to this theme have been carried out so far; thus, further studies investigating the effect of the administration of other polyphenols (resveratrol, etc.) in COVID-19 patients are warranted.

\section{Acknowledgments}

The authors thank Ricky Toledano for revision of the English version of the manuscript. Gustavo Oliveira and Mônica Volino-Souza acknowledge the financial support provided by the Fundação Carlos Chagas de Amparo à Pesquisa do Estado do Rio de Janeiro - FAPERJ (E-26/200.021/2020) and Coordenação de Aperfeiçoamento de Pessoal de Nível Superior (Brazil), 
respectively. GVO, MV-S, KSS, and YSM have written the manuscript. CAC-J and TSA have revised the manuscript.

\section{References}

Annunziata, G., Maisto, M., Schisano, C., Ciampaglia, R., Narciso, V., Tenore, G. C., \& Novellino, E. (2018). Resveratrol as a novel anti-herpes simplex virus nutraceutical agent: an overview. Viruses, 10(9), 473.

Annunziata, G., Sanduzzi Zamparelli, M., Santoro, C., Ciampaglia, R., Stornaiuolo, M., Tenore, G. C., \& Novellino, E. (2020). May polyphenols have a role against coronavirus infection? An overview of in vitro evidence. Frontiers in Medicine, 7, 240.

Babaei, F., Nassiri-Asl, M., \& Hosseinzadeh, H. (2020). Curcumin (a constituent of turmeric): New treatment option against COVID-19. Food science \& nutrition, 8(10), 5215-5227.

Chojnacka, K., Witek-Krowiak, A., Skrzypczak, D., Mikula, K., \& Młynarz, P. (2020). Phytochemicals containing biologically active polyphenols as an effective agent against Covid-19-inducing coronavirus. Journal of Functional Foods, 104146

De Leo, A., Arena, G., Lacanna, E., Oliviero, G., Colavita, F., \& Mattia, E. (2012). Resveratrol inhibits Epstein Barr Virus lytic cycle in Burkitt's lymphoma cells by affecting multiple molecular targets. Antiviral Research, 96(2), 196-202.

de Oliveira, G. V., Volino-Souza, M., Conte-Júnior, C. A., \& Alvares, T. S. (2021). Food-derived polyphenol compounds and cardiovascular health: a nanotechnological perspective. Food Bioscience, 101033.

Faith, S. A., Sweet, T. J., Bailey, E., Booth, T., \& Docherty, J. J. (2006). Resveratrol suppresses nuclear factor- $\kappa B$ in herpes simplex virus infected cells. Antiviral Research, 72(3), 242-251.

Gupta, S. C., Patchva, S., \& Aggarwal, B. B. (2013). Therapeutic roles of curcumin: lessons learned from clinical trials. The AAPS journal, 15(1), 195-218.

Hamming, I., Timens, W., Bulthuis, M. L. C., Lely, A. T., Navis, G. V., \& van Goor, H. (2004). Tissue distribution of ACE2 protein, the functional receptor for SARS coronavirus. A first step in understanding SARS pathogenesis. The Journal of Pathology: A Journal of the Pathological Society of Great Britain and Ireland, 203(2), 631-637.

Hanuka Katz, I., Eran Nagar, E., Okun, Z., \& Shpigelman, A. (2020). The Link between polyphenol structure, antioxidant capacity and shelf-life stability in the presence of fructose and ascorbic acid. Molecules, 25(1), 225.

Levy, E., Delvin, E., Marcil, V., \& Spahis, S. (2020). Can phytotherapy with polyphenols serve as a powerful approach for the prevention and therapy tool of novel coronavirus disease 2019 (COVID-19)?. American Journal of Physiology-Endocrinology and Metabolism, 319(4), E689-E708.

Li, H., Wu, J., Zhang, Z., Ma, Y., Liao, F., Zhang, Y., \& Wu, G. (2011). Forsythoside a inhibits the avian infectious bronchitis virus in cell culture. Phytotherapy Research, 25(3), 338-342.

Lin, C. J., Lin, H. J., Chen, T. H., Hsu, Y. A., Liu, C. S., Hwang, G. Y., \& Wan, L. (2015). Polygonum cuspidatum and its active components inhibit replication of the influenza virus through toll-like receptor 9-induced interferon beta expression. PLoS One, 10(2), e0117602.

Lin, S. C., Ho, C. T., Chuo, W. H., Li, S., Wang, T. T., \& Lin, C. C. (2017). Effective inhibition of MERS-CoV infection by resveratrol. BMC Infectious Diseases, 17(1), 1-10.

Liu, T., Zang, N., Zhou, N., Li, W., Xie, X., Deng, Y., \& Liu, E. (2014). Resveratrol inhibits the TRIF-dependent pathway by upregulating sterile alpha and armadillo motif protein, contributing to anti-inflammatory effects after respiratory syncytial virus infection. Journal of Virology, 88(8), $4229-4236$.

Manach, C., Scalbert, A., Morand, C., Rémésy, C., \& Jiménez, L. (2004). Polyphenols: food sources and bioavailability. The American Journal of Clinical Nutrition, 79(5), 727-747.

Pang, X. F., Zhang, L. H., Bai, F., Wang, N. P., Garner, R. E., McKallip, R. J., \& Zhao, Z. Q. (2015). Attenuation of myocardial fibrosis with curcumin is mediated by modulating expression of angiotensin II AT1/AT2 receptors and ACE2 in rats. Drug design, development and therapy, $9,6043$.

Roh, C. (2012). A facile inhibitor screening of SARS coronavirus N protein using nanoparticle-based RNA oligonucleotide. International Journal of Nanomedicine, 7, 2173.

Saber-Moghaddam, N., Salari, S., Hejazi, S., Amini, M., Taherzadeh, Z., Eslami, S., \& Elyasi, S. (2021). Oral nano-curcumin formulation efficacy in management of mild to moderate hospitalized coronavirus disease-19 patients: An open label nonrandomized clinical trial. Phytotherapy Research.

Sasaki, H., Sunagawa, Y., Takahashi, K., Imaizumi, A., Fukuda, H., Hashimoto, T., \& Morimoto, T. (2011). Innovative preparation of curcumin for improved oral bioavailability. Biological and Pharmaceutical Bulletin, 34(5), 660-665.

Shang, J., Wan, Y., Luo, C., Ye, G., Geng, Q., Auerbach, A., \& Li, F. (2020). Cell entry mechanisms of SARS-CoV-2. Proceedings of the National Academy of Sciences, 117(21), 11727-11734.

Soni, V. K., Mehta, A., Ratre, Y. K., Tiwari, A. K., Amit, A., Singh, R. P., \& Vishvakarma, N. K. (2020). Curcumin, a traditional spice component, can hold the promise against COVID-19? European Journal of Pharmacology, 173551.

Valizadeh, H., Abdolmohammadi-Vahid, S., Danshina, S., Gencer, M. Z., Ammari, A., Sadeghi, A., \& Ahmadi, M. (2020). Nano-curcumin therapy, a promising method in modulating inflammatory cytokines in COVID-19 patients. International Immunopharmacology, 89, 107088. 
Volino-Souza, M., de Oliveira, G. V., Conte-Junior, C. A., \& Alvares, T. S. (2020). Covid-19 quarantine: impact of lifestyle behaviors changes on endothelial function and possible protective effect of beetroot juice. Frontiers in Nutrition, 7.

Yiu, C. Y., Chen, S. Y., Chang, L. K., Chiu, Y. F., \& Lin, T. P. (2010). Inhibitory effects of resveratrol on the Epstein-Barr virus lytic cycle. Molecules, 15(10), 7115-7124.

Zang, N., Xie, X., Deng, Y., Wu, S., Wang, L., Peng, C., \& Liu, E. (2011). Resveratrol-mediated gamma interferon reduction prevents airway inflammation and airway hyperresponsiveness in respiratory syncytial virus-infected immunocompromised mice. Journal of Virology, 85(24), 13061-13068.

Zhang, L., Li, Y., Gu, Z., Wang, Y., Shi, M., Ji, Y., \& Shi, W. (2015). Resveratrol inhibits enterovirus 71 replication and pro-inflammatory cytokine secretion in rhabdosarcoma cells through blocking IKKs/NF-kB signaling pathway. PloS One, 10(2), e0116879.

Zhu, N., Zhang, D., Wang, W., Li, X., Yang, B., Song, J., \& Tan, W. (2020). China Novel Coronavirus Investigating and Research Team. A novel coronavirus from patients with pneumonia in China, 2019. N Engl J Med, 382(8), 727-733. 